\title{
EFFECT OF HIGH HYDROSTATIC PRESSURE AT 400 MPA ON QUALITY ATTRIBUTES OF LIQUID EGG PRODUCTS
}

\author{
AdRienn Tóth ${ }^{1}$, CSABa NÉMETH ${ }^{2}$, RéKa JUHÁSZ ${ }^{3}$, ILdikó ZEKE ${ }^{1}$, BERTOLD \\ SALAMON $^{1}$, DóRA BÉNYI ${ }^{1}$, LÁSZló FRIEdRICH ${ }^{1}$ \\ ${ }^{1}$ Szent István University Department of Refrigeration and Livestock Products' Technology, \\ Budapest Hungary \\ ${ }^{2}$ Capriovus Kft. Szigetcsép Hungary \\ ${ }^{3}$ Szent István University Department of Food Preservation \\ toth.adrienn@etk.szie.hu
}

\begin{abstract}
Samples prepared from liquid egg yolk (LEY), liquid egg white (LEW) and liquid whole egg (LWE) were processed by high hydrostatic pressure (HHP) using different holding times $(60,180,300,420$ and $600 \mathrm{~s})$. The aim of our experiment was to examine how different holding times influences technofunctional attributes of liquid egg products.

The color of samples changed after $60 \mathrm{~s}$ HHP treatment, but visible changes were evaluated just after 180$300 \mathrm{~s}$. The $\mathrm{pH}$ of samples was stable, there were no significant changes caused by HHP (one-way ANOVA, $\alpha=0,05)$.

The apparent viscosity was measured by a rotational viscometer as a function of shear rate. The shearthinning behavior of LEY and pseudopastic behavior of LEW and LWE were fitted well into HerschelBulkley model (with a satisfying correlation of $\mathrm{R}^{2}>0.96$ ). For the selected shearing rate, viscosity was measured in relation to shearing time. Thixotropic behavior of samples was increased by longer holding time of HHP treatments.
\end{abstract}

Keywords: high hydrostatic pressure, egg products, viscosity, technofunctional properties

\section{INTRODUCTION}

Eggs have been classified as nature's original functional food (HASLER, 2000). In present there is a tendency to use more and more eggshell processed products where term egg products refers to eggs that are removed from their shells (DE JESÚS ET AL., 2013).

Hen's egg yolk is an important ingredient of a wide variety of food products. In addition to its excellent emulsifying activity, its ability to form gels when heated is the basis of major applications of egg yolk. This characteristic property originates from protein interactions (Kiosseoglou AND PARAsKevopoulou, 2005) and is decisive in determining the desired rheological and textural characteristics of foods such as bakery products, egg-based sauces, omelets, confectionery, etc. However, in thermally treated products such as pasteurized liquid egg yolk, gel network formation can cause unpredictable structure changes through protein denaturation (KIOSSEOGLOU AND PARASKEVOPOULOU, 2005) than egg yolk proteins are particularly thermosensitive (AnTon, Le Denmat, BeAumal, \& Pilet, 2001). These changes can occur undesirably during pasteurization, food processing, and preparation, leading to a loss of product fluidity. Changes in thermally induced egg yolk gels can be provoked by different technological factors e.g. pH (CORDOBÉS ET AL., 2004; Kiosseoglou And Paraskevopoulou, 2005). Knowledge of the influence of these factors makes it possible to apply them advantageously to obtain foods with an optimal texture and extended shelf life. Whereas several references are available on the influence of pasteurization, freeze-drying, and salts on the properties of egg yolk gels, the mechanisms are not completely understood by which these treatments induce the 
conformational changes in the secondary structure of egg yolk proteins which are causally involved in gel formation (BLUME ET.AL., 2015).

The changes of rheological properties significantly related with flow transport of liquid egg product. It is important knowledge of flow velocity profiles in real tubes and pipes, which are used to transport, cooling, drying, and pasteurization. Part of this problem is described in (de SouZA AND FERNÁNDEZ, 2013). Most of these studies have been usually carried out with only egg yolk. There is a lack of information about the rheological behaviour of liquid egg white and whole egg at different temperature range (TELIS-ROMERO ET AL., 2006).

The use of eggshell processed products (e.g. boiled eggs, liquid whole egg, liquid egg yolk and liquid egg white) is widely expanded in food industry because of easier utility, better food safety. Technofunctional properties of liquid egg products, like color, viscosity, foaming ability have extraordinary importance in terms of further industrial processing. Native attributes of egg products are expected by food producers, therefore minimal processing techniques of food preservation are constantly under development. One of the most prosperous methods is high hydrostatic pressure (HHP). HHP is a nonthermal preservation technology using hydrostatic pressure between 100 and $1000 \mathrm{MPa}$ in food preservation. The aim of our experiment was to evaluate effects of holding time, as a parameter of HHP treatment.

\section{MATERIAL AND METHOD}

\section{Sample preparing}

Samples were taken from processing line of Capriovus Ltd. We used homogenized liquid whole egg (LWE), liquid egg yolk (LEY) and liquid egg white (LEW). From every product $500-500 \mathrm{ml}$ of samples were packaged in PE bags. Samples were treated on $400 \mathrm{MPa}$ in RESATO FPU 100-2000 laboratory HHP equipment with holding times: 30, 180, 300, 420 and $600 \mathrm{~s}$ at room temperature. Samples were stored at $4-6{ }^{\circ} \mathrm{C}$ before measurements.

\section{Color}

Minolta Cr 200 colorimeter was applied to evaluate color of samples. From L*, a* and b* (CIE-Lab color system) color difference $\Delta \mathrm{E}_{\mathrm{ab}}{ }^{*}$ was counted to compare color of samples to control, untreated product. Differences in color were analyzed statistically with one way ANOVA and post hoc tests (SPSS 20.0 software, $\alpha=0,05$ ).

\section{pH-value}

The $\mathrm{pH}$ of egg products was controlled with Testo $206 \mathrm{pH}$-meter. Statistical analyze of $\mathrm{pH}$ was carried out with one-way ANOVA (SPSS 20.0 software, $\alpha=0,05$ ).

\section{Rheological properties}

In Department of Food Preservation rheological attributes were measured with Anton Paar Physica MCR 51 rotational viscometer at $5{ }^{\circ} \mathrm{C}$. Shear stress was measured in function of shear rate, Herschel-Bulkley model and thixotropy of samples were evaluated.

\section{RESULTS}

\section{Color}

LEW became brighter ( $\mathrm{L}^{*}$ increased) affected by longer holding time. Color factors $\mathrm{a}^{*}$ and $b^{*}$ in case of LEW were not significantly influenced, but changes in color of samples were 
visible after $180 \mathrm{~s}$ HHP treatment. Statistically significant differences were evaluated after $180 \mathrm{~s}$ to control and between treated samples treated with longer holding time.

LEY's color became brighter ( $\mathrm{L}^{*}$ increased) such $\mathrm{b}^{*}$, namely yellow color became stronger. Changes increased effected longer holding time. In case of $a^{*}$ growing of value was experienced $(60 \mathrm{~s})$ but HHP with longer holding times resulted $\mathrm{a}^{*}$ values like control's. There were statistically significant differences already after $60 \mathrm{~s}$ HHP treatment. In color of LWE there were a tendency, like in case of LEY: color of $60 \mathrm{~s}$ treated sample showed significant differences values. Longer holding times influenced less color of LWE.

\section{pH}

In case of LEY there were no changes, $\mathrm{pH}$ was measured between 5,49 and $5,66 \mathrm{pH}$ of LEW showed a similar stability. The pH of LWE was only significant influenced by HHP treatment with 60 and $180 \mathrm{~s}, \mathrm{pH}$ changed between 4,5 and 5,0.

\section{Rheological properties}

The apparent viscosity was measured by the rotational viscometer as a function of shear rate. Yield curves of control and $600 \mathrm{~s}$ treated samples are shown in Figure 1 (LWE), 2 (LEW) and 3 (LEY). As it can be seen apparent viscosity and yield curves are changed effected by HHP treatment (treated samples are more "viscous"). Longer HHP treatment resulted higher differences and already $60 \mathrm{~s}$ HHP treatment changed rheological properties significantly.

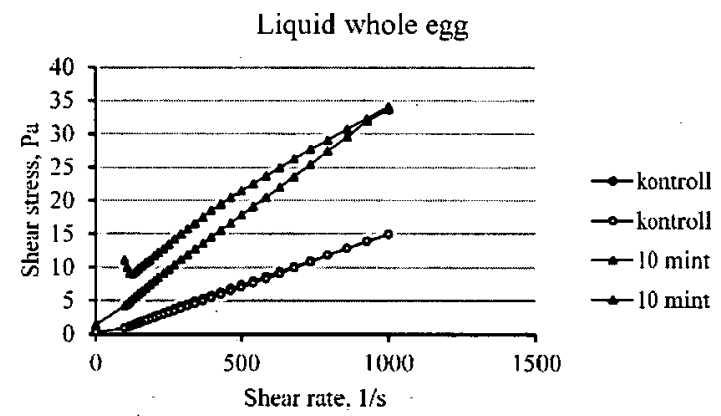

Figure 1. Yield curve of LWE control and $400 \mathrm{MPa}, 600 \mathrm{~s}$ treated samples

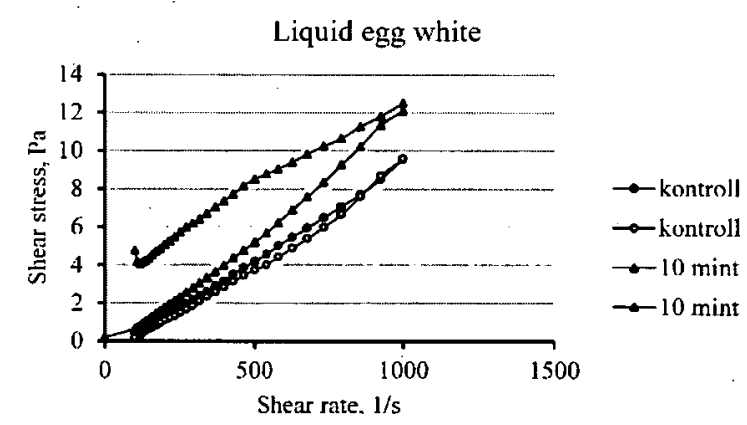

Figure 2. Yield curve of LEW control and $400 \mathrm{MPa}, 600 \mathrm{~s}$ treated samples

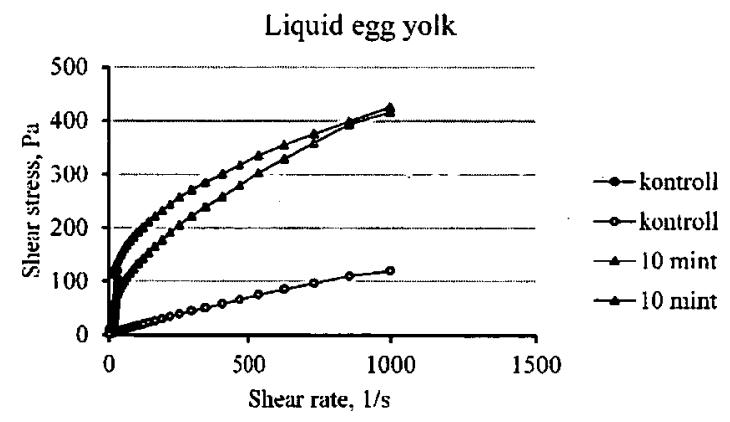

Figure 3. Yield curve of LEY control and $400 \mathrm{MPa}, 600 \mathrm{~s}$ treated samples

Herschel-Bulkley model was applied to evaluate rheological results. Table 1 shows $\mathrm{n}[-]$ flow behavior index of samples. Control LWE can be accepted as almost Nemwtonial fluid, longer HHP treatment caused increasing pseudoplastic attributes. LEW's n parameter decreased by longer HHP processing, but after $600 \mathrm{~s}$ it was pseudoplastic fluid. In case of egg yolk flow behavior index was not influenced by HHP, LEY can be considered as a gear-thickening fluid. 
Review on Agriculture and Rural Development 2016 vol. 5 (1-2) ISSN 2063-4803

Table 1. Flow behavior index of HHP treated liquid egg samples at $400 \mathrm{MPa}$

\begin{tabular}{|c|c|c|c|c|c|c|}
\hline $\mathbf{n}$ & \multicolumn{2}{|c|}{ LWE } & \multicolumn{2}{c|}{ LEW } & \multicolumn{2}{c|}{ LEY } \\
\hline HHP & average & $\begin{array}{c}\text { st. } \\
\text { deviation }\end{array}$ & average & $\begin{array}{c}\text { st. } \\
\text { deviation }\end{array}$ & average & $\begin{array}{c}\text { st. } \\
\text { deviation }\end{array}$ \\
\hline control & 0,933 & 0,018 & 1,150 & 0,049 & 0,757 & 0,005 \\
\hline $1 \mathrm{~min}$ & 0,856 & 0,035 & 1,516 & 0,017 & 0,757 & 0,005 \\
\hline $3 \mathrm{~min}$ & 0,856 & 0,035 & 1,646 & 0,037 & 0,757 & 0,005 \\
\hline $5 \mathrm{~min}$ & 0,757 & 0,005 & 1,412 & 0,062 & 0,757 & 0,005 \\
\hline $7 \mathrm{~min}$ & 0,757 & 0,008 & 1,412 & 0,149 & 0,757 & 0,005 \\
\hline $10 \mathrm{~min}$ & 0,748 & 0,022 & 1,024 & 0,068 & 0,757 & 0,005 \\
\hline $\mathrm{n}=1 \mathrm{Newtonial} \mathrm{fluid}$ & $\mathrm{n}<1$ pseudoplastic & \multicolumn{5}{c|}{$\mathrm{n}>1$ shear-thickening } \\
\hline
\end{tabular}

The shear-thinning behavior of LEY, pseudoplastic behavior of LEW and LWE were fitted well into Herschel-Bulkley model (with a satisfying correlation of $\mathrm{R}^{2}>0.96$ ). For the selected shearing rate, viscosity was measured in relation to shearing time. The timedependent viscosity decreased rapidly with time and, at lower share rates, reached an equilibrium state. The time-dependent viscosity was also found to increase with holding time.

Table 2. Thixotropic behavior of liquid egg samples

\begin{tabular}{|l|c|c|c|c|c|c|}
\hline A [Pas] & \multicolumn{2}{|c|}{ LWE } & \multicolumn{2}{c|}{ LEW } & \multicolumn{2}{c|}{ LEY } \\
\hline thixotropy & average & st. deviation & $\begin{array}{c}\text { averag } \\
\mathrm{e}\end{array}$ & st. deviation & average & st. deviation \\
\hline control & 378,17 & 43,72 & 418,02 & 46,68 & 100 & 0,00 \\
\hline $1 \mathrm{~min}$ & 4146,39 & 5,74 & 816,32 & 34,52 & 13254,50 & 341,08 \\
\hline $3 \mathrm{~min}$ & 4146,39 & 5,74 & 1319,52 & 31,89 & 17757,84 & 3691,56 \\
\hline $5 \mathrm{~min}$ & 3898,72 & 54,92 & 1945,01 & 13,80 & 24805,85 & 258,72 \\
\hline 7 min & 3244,47 & 58,50 & 2081,22 & 12,86 & 31688,03 & 349,83 \\
\hline $10 \mathrm{~min}$ & 2959,08 & 14,24 & 2380,13 & 183,09 & 40303,48 & 959,64 \\
\hline
\end{tabular}

Thixotropic behavior of samples is shown in Table 2. In every sample there is the phenomenon that is caused by mechanical stress. HHP treatment increased thixotropy in every case. Application of longer holding time caused increasing thixotropy. HHP caused heavier mixable or flowable samples.

\section{CONCLUSIONS}

HHP treatment at $400 \mathrm{MPa}$ can be an opportunity to preserve liquid egg products combined with other minimal processing e.g. heat treatment with low temperature. Knowing the impact of holding time on different technofunctional properties, like color or viscosity has outstanding importance because of industrial applications and processing. 


\section{ACKNOWLEDGEMENTS}

We owe thanks for all colleagues of Department of Refrigeration and Livestock Products Technology, Department of Food Preservation and Capriovus Ltd.

\section{REFERENCES}

Blume, K, Dietrich, K., Lilien, S., Temes, W., Drotleff, A.M. (2015): Exploring the relationship between protein secondary structures, temperature-dependent viscosities, and technological treatments in egg yolk and LDL by FTIR and rheology. Food Chemistry 173: 584-593.

Kiosseoglou, V., Paraskevopoulou, A. (2005): Molecular interactions in gels prepared with egg yolk and its fractions. Food Hydrocolloids 19: 527-532.

Anton, M., Le Denmat, M, Beaumal, V., Pilet, P. (2001): Filler effects of oil droplets on the rheology of heat-set emulsion gels prepared with egg yolk and egg yolk fractions Colloids and Surfaces B: Biointerfaces 21(1-3): 137-147.

Cordobés, F, PArtal, P., Guerrero, A. (2004): Rheology and microstructure of heatinduced egg yolk gels. Rheologica Acta 43(2): 184-195.

HASLER, C.M. (2000): The changing face of functional foods. J. Am. Coll. Nutr. 19(5): 499-506.

de Jesús, M.N., Zanqui, A.B., Valderrama, P., Tanamati, A., Maruyama, S.A., de SouzA, N.E., MatsushitA, M. (2013): Sensory and physico-chemical characteristics of desserts prepared with egg products processed by freeze and spray drying. Food Sci. Technol. 33(3): 549-554.

Telis-Romero, J, Thomaz, C.E.P., Bernardi, M., Telis, V.R.N., Gabas, A.L. (2006): Rheological properties and fluid dynamics of egg yolk. J. Food Eng. 74: 191-197.

DE SouzA, P.M. and Fernández A. (2013): Rheological properties and protein quality of UV-C processed liquid egg products. Food Hydrocolloids 31(1): 127-134. 